\title{
SWOT ANALYSIS OF SHEEP AND GOAT REARING PRACTICES of Bakarwal TRIBE IN JAMMU DISTRICT OF JAMMU AND KASHMIR
}

\author{
Farzana Choudhary, S. A. Khandi, Rayees Ahmed Bafanda*, Fahad Shehjar \\ Division of Veterinary and Animal Husbandry Extension Education, Sher-e-Kashmir University of Agricultural Sciences and Technology of Jammu(SKUAST-J), \\ R.S.PURA, Jammu-181102, India
}

Received - July 17, 2018; Revision - September 14, 2018; Accepted - September 29, 2018

Available Online - October 5, 2018

DOI: http://dx.doi.org/10.18006/2018.6(5).898.902

KEYWORDS
SWOT
Bakarwal
Sheep
Goat
Rearing practices

Rearing practices

\begin{abstract}
Bakarwals, one of the tribal communities of Jammu \& Kashmir forming largest small ruminant rearing pastoralist groups in Himalayan region of $J \& K$. Small ruminant rearing significantly contributes to the livelihood security of the poor farmers, even under various challenging environmental conditions as inadequate rainfall, very high temperatures and poor soil fertility. The present study was conducted in Jammu district of Jammu and Kashmir state to assess the SWOT analysis of Bakarwal tribe regarding sheep and goat rearing practices. Multistage random sampling plan was followed for the selection of ultimate respondents. The data was collected from 120 Bakarwal respondents belonging to Marh, Satwari, Bhalwal and Dansal blocks of Jammu district through well structured interview schedule, from the respondents either at their farm or home after proper testing of schedule and using appropriate scales. The final schedule was divided into four broad areas namely strength, weakness, opportunity and threat, each area consisted of 6 items. This was operationalised on a two point continuum of Yes and No. with 1 and 0 score allotted respectively for each items. The scores of individual items were added to arrive at the total score of an individual respondent. The findings revealed that rearing sheep and goat through "traditional rearing practices do not need high start up costs to establish a profitable business" was the main strength in sheep and goat rearing (99.17\%), while "traditional sheep and goat rearing knowledge" was the least strength (50\%). "Inaccessible paths to the sheep and goat rearer" (98.83\%) was considered as the main weaknesses whereas, "local breeds have low productivity in terms of wool
\end{abstract}

* Corresponding author

E-mail: rayeesahmed372@gmail.com (Rayees Ahmed Bafanda)

Peer review under responsibility of Journal of Experimental Biology and Agricultural Sciences.

Production and Hosting by Horizon Publisher India [HPI] (http://www.horizonpublisherindia.in/).

All rights reserved.
All the article published by Journal of Experimental Biology and Agricultural Sciences is licensed under a Creative Commons Attribution-NonCommercial 4.0 International License Based on a work at www.jebas.org.

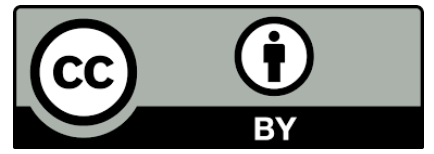


production, milk production and meat due to genetic limitations" was considered as least weakness $(60 \%)$ in sheep and goat rearing. While "sheep and goat can be used as a tool to alleviate poverty while also ensuring food security", was the main opportunity in sheep and goat rearing $(99.17 \%)$ whereas "processing to add value to sheep and goat products" was considered as least opportunity (45\%). Grazing areas are of difficult access to the shepherd" was the main threat $(99.17 \%)$ whereas, "sheep grazing causes deforestation" was considered as least threat $(70 \%)$ in sheep and goat rearing by Bakarwal tribe.

\section{Introduction}

Sheep and goat have an inseparable identity with the farmers in India from time immemorial. They constitute an important component of agriculture and economy of the farming community in India, especially those of the weaker sections among agriculturists. In addition they form substantially useful fraction if their total farm income particularly, when crops fail due to drought and other adverse conditions. Sheep and goat are an important and integral part of rural economy that can be reared under adverse climatic conditions and in areas with scanty vegetation and low rainfall. In India, sheep is the major source of meat and wool; goats are reared for milk in addition to meat (Kumara et al., 2017). In India, small ruminants like sheep have a most important role in the utilization of vast areas of grazing land throughout the country (Arora \& Garg, 1998). The lands whether arid, semi-arid or hilly have characteristics which preclude cultivation and crop production. However, these regions permit pastoral agriculture using the grazing animal like sheep and goat to convert the natural vegetation into products useful to man. The natural characteristics of sheep and the diversity of their functions, adaptability and performance have combined to establish their wide, distribution throughout the country. Besides their wellrecognized contribution to human needs for meat, fiber and milk, they provide a living and a way of life for millions of land less and marginal farmers of our country (Anonymous, 2010).

Sheep and goat are main source of livelihood of Bakarwals tribe in Jammu and Kashmir. Bakarwals, one of the tribal communities of Jammu \& Kashmir forming largest small ruminant rearing pastoralist groups in Himalayan region of J\&K (Choudhary, 1999). They are socially, economically and politically marginalized group of people who are mostly living below poverty line and have very little access to the various social, educational and health services provided by the state government (Choudhary, 1999). Bakerwals are primarily pastoral nomads rearing goat and sheep in high altitudes of greater Himalayas during summer and spend their winter in plains and foot hills of Shiwaliks (Rafaqi 2014). They are special nomadic tribes mainly found in the Peerpanjal range of mountains located between the two states of Jammu \& Kashmir and Himachal Pradesh.
Bakerwals plan their activities into four major segments of time: winter, spring, summer and autumn. Secondly, they act on space and plan their activities in outer hills (winter pastures) on migratory routes and Dhoks (summer pastures) (Rafaqi, 2014).

The Bakarwal tribes are not yet aware about the scientific production and management practices of sheep and goat rearing. If all the scientific production and management practices are properly operated, then it would be possible to reach the desired level of milk and meat production. It is necessary to introduce superior technologies for adoption of improved production and management practices in goat rearing. The management practices followed by the sheep and goat keepers are different from region to region. Understanding the management practices adopted by the farmers is necessary to identify the strengths and weaknesses of the sheep and goat production system and to formulate suitable intervention policies. Keeping the above mentioned factors in mind, a study was undertaken entitled "Swot analysis of sheep and goat rearing practices of Bakarwal Tribe", that will generate useful information about the Bakarwal tribe regarding "strength and weakness of small ruminants rearing practices that, can be matched with the opportunities and threats operating in the farm condition so that an effective strategy can be formulated.

\section{Materials and Methods}

The present study was conducted in Jammu district of Jammu and Kashmir with the objectives to access the SWOT analysis of sheep and goat rearing practices of Bakarwal tribe. Jammu district comprises of twenty blocks. Out of these four blocks Marh, Dansal, Satwari and Bhalwa were selected purposefully having predominant Bakarwal population. A list of respondents involved in sheep and goat rearing were prepared from selected blocks. Thirty Bakarwals were selected randomly from each of the 4 selected blocks of Jammu district, making a sample size of 120 respondents. Data were collected from the study area with the help of a pre-structured interview schedule after proper pre-testing and modifications. The final schedule was divided into four broad areas namely strength, weakness, opportunity and threat (SWOT). Strength is that factor that makes practices more competitive; weakness is a limitation, fault within practices that will keep it 
from achieving its objectives; opportunities as any favourable current perspective situation and threat as any unfavourable situation that is currently damaging its ability. The final schedule consisted of 6 items in each area of strength, weakness, opportunity and threats, respectively. This was operationalised on a two point continuum of Yes and No. with 1 and 0 score allotted respectively for each items. The scores of individual items were added to arrive at the total score of an individual respondent. The total score of all respondents was divided by the maximum possible score and multiplied by 100 to arrive at the final existing practices score by using formula:

\section{Mean Percent Score $($ MPS $)=($ Observed score $/$ Total score $) \times 100$}

\section{Results and Discussion}

SWOT analysis is a strategic planning method used to evaluate the strengths, weaknesses, limitations, opportunities and threats involved in a project or in a business venture. It involves identifying the internal and external factors that are favourable and unfavourable to achieve the specific goal of the project or programme. Internal environmental factors include risk taking abilities, human resource capabilities and financial strength. External factors include competition, government schemes, changing trends and social expectations. The SWOT analysis framework involves analyzing the strengths (S) and weakness (W) of the internal factors and the opportunities $(\mathrm{O})$ and threats $(\mathrm{T})$ of its external factors of performance. Through this analysis "strength and weakness within a project or in a business venture can be matched with the opportunities and threats operating in the environment so that an effective strategy can be formulated". Therefore, an effective strategy can be derived by taking advantage of its opportunities by using its strength and neutralize its threat by minimizing the impact of its weakness. This section identifies and prioritizes the strengths, weaknesses, opportunities and threats faced by Bakarwal tribe regarding sheep and goat rearing practices. The results obtained after performing the SWOT analysis of Bakarwal tribe regarding sheep and goat rearing practices by using semi- structured interview schedule and quantification of the Strengths, Weaknesses, Opportunities and Threats are presented in the tables below:

\subsection{Strength analysis}

The strengths of sheep and goat rearing practices of Bakarwal Tribe were presented in table 1 . The study revealed small ruminant rearing is profitable business as $99.17 \%$ of the respondents responses that rearing of sheep and goat through traditional practices and less cost to start up was the main strength in sheep and goat rearing while "traditional sheep and goat rearing knowledge" was the least strengthen factor (50\%). The other important strengths were "producing food for own consumption" (98.33\%), "reliable source of income for livelihood of social and economically backward Bakarwal tribe" (85\%), "market availability for sheep and goat products"(68.33\%) and "emergency source of income" $(65 \%)$ in sheep and goat rearing. Similarly Lidga et al. (2013) and Gupta et.al (2016), revealed that the major strengths of pastoral and rangeland sheep and goat production systems were rich biodiversity and natural environment; local farm animal breeds adapted to the environment and low input production systems. Bosch et al. (2012) reported that the main strengths of sheep farms were grazing resources, local breeds adapted to the exploitation of such resources and proximity to consumers.

\subsection{Weakness Analysis}

The data of the table 2 revealed that "inaccessible paths to the sheep and goat rearer" (98.83\%) and "absence of a fixed monthly salary" $(96.67 \%)$ were considered as the main weaknesses in sheep and goat rearing. Whereas, "local breeds have low productivity in terms of wool production, milk production and meat due to genetic limitations" was considered as least weakness (60\%). Other weaknesses were "lack of good management practices during disease condition (86.67\%), "low education level of sheep and goat rearer" $(83.33 \%)$ and "increased work load" (80\%). Similarly, Bosch et al. (2012) reported that the main weaknesses were conflicts in land use (access to grazing areas,

Table 1: Strength analysis of sheep and goat rearing practices of Bakarwal tribe

\begin{tabular}{|clcccc|}
\hline S.No. & \multicolumn{1}{c}{ Strength } & Score Obtained & Mean Score & MPS & Rank \\
\hline 1. & $\begin{array}{l}\text { Rearing of sheep and goat through tradition practices and } \\
\text { less cost to start up a profitable business }\end{array}$ & 119 & 0.99 & 99.17 & 1 \\
\hline 2. & $\begin{array}{l}\text { Reliable source of income for livelihood of backward } \\
\text { Bakarwal tribe }\end{array}$ & 102 & 0.85 & 85 & 3 \\
\hline 3. & Emergency source of income & 78 & 0.65 & 65 & 5 \\
\hline 4. & Traditional sheep and goat rearing knowledge & 60 & 0.5 & 50 & 6 \\
\hline 5. & Market availability for sheep and goat products & 82 & 0.68 & 68.33 & 4 \\
\hline 6. & Produce food for own consumption & 118 & 0.98 & 98.33 & 2 \\
\hline
\end{tabular}


pressure from other uses), small size and dependency on subsidies. Lidga et al. (2013) revealed that the major weaknesses were lack of appropriate strategies, lack of rational organization of community pastures and lack of vocational trainings. From the analysis of the weaknesses, it is clear that there is good scope for turning the weaknesses into strengths of the organization.

\subsection{Opportunity Analysis}

The data of the table 3 revealed that " sheep and goat can be used as a tool to alleviate poverty while also ensuring food security", was the main opportunity in sheep and goat rearing (99.17\%). Whereas "processing to add value to sheep and goat products" was considered as least opportunity (45\%). Other important opportunities were "self empowerment and entrepreneurship development" (78.33\%) followed by "marketing of meat and wool could be organized" (76.67\%), "maximizing of production to take a advantage of economics of sale" (73.33\%) and "lack of alternatives to agricultural activity" (70\%). Similarly, Legese \& Fadiga (2014) reported that the important opportunities were suitable agro-ecology to produce different livestock species, availability of a significant livestock population and increasing domestic and international demand for meat.

\section{4 Threat Analysis}

A cursory look at the table 4 revealed that "grazing areas are of difficult access to the shepherd" was the main threat in sheep and

Table 2 Weakness analysis of sheep and goat rearing practices of Bakarwal

\begin{tabular}{|c|c|c|c|c|c|}
\hline S. No & Weakness & Score Obtained & Mean Score & MPS & Rank \\
\hline 1. & Absence of a fixed monthly salary & 116 & 0.97 & 96.67 & 2 \\
\hline 2. & Low education level of sheep and goat rearer. & 100 & 0.83 & 83.33 & 4 \\
\hline 3. & Lack of good management practices during disease condition & 104 & 0.87 & 86.67 & 3 \\
\hline 4. & Increased work load & 96 & 0.8 & 80 & 5 \\
\hline 5. & $\begin{array}{l}\text { Local breeds have low productivity in terms of wool production, milk } \\
\text { production and meat due to genetic limitations. }\end{array}$ & 72 & 0.6 & 60 & 6 \\
\hline 6. & Inaccessible paths to the sheep and goat rarer & 118 & 0.98 & 98.33 & 1 \\
\hline
\end{tabular}

Table 3 Opportunity analysis of sheep and goat rearing practices of Bakarwal

\begin{tabular}{|clcccc|}
\hline S. No. & \multicolumn{1}{c}{ Opportunity } & Score Obtained & Mean Score & MPS & Rank \\
\hline 1 & $\begin{array}{l}\text { Sheep and goat can be used as a tool to alleviate poverty while also } \\
\text { ensuring food security }\end{array}$ & 119 & 0.99 & 99.17 & 1 \\
\hline 2. & Maximizing of production to take a advantage of economics of sale & 88 & 0.73 & 73.33 & 4 \\
\hline 3. & Processing to add value to sheep and goat products & 54 & 0.45 & 45 \\
\hline 4. & Marketing of meat and wool could be organized & 92 & 0.77 & 76.67 & 3 \\
\hline 5. & Self empowerment and entrepreneurship development & 94 & 0.78 & 78.33 & 2 \\
\hline 6. & Lack of alternatives to agricultural activity & 84 & 0.7 & 70 \\
\hline
\end{tabular}

Table 4 Threat analysis of sheep and goat rearing practices of Bakarwal

\begin{tabular}{|clcccc|}
\hline S. No. & \multicolumn{1}{c}{ Threat } & Score Obtained & Mean Score & MPS & Rank \\
\hline 1. & Grazing areas are of difficult access to the shepherd. & 119 & 0.99 & 99.17 & 1 \\
\hline 2. & Social discrimination of the shepherd. & 117 & 0.98 & 97.5 & 2 \\
\hline 3. & An outbreak of epidemics & 110 & 0.92 & 91.67 & 4 \\
\hline 4. & Management practices & 90 & 0.75 & 75 & 5 \\
\hline 5. & Sheep grazing causes deforestation & 84 & 0.7 & 70 & 6 \\
\hline 6. & Forester do not allow for grazing in forest land & 116 & 0.97 & 96.67 & 3 \\
\hline
\end{tabular}


goat rearing $(99.17 \%)$. Whereas, "sheep grazing causes deforestation" was considered as least threat (70\%). Other threats were "social discrimination of the shepherd" (97.5\%); "forester do not allow for grazing in forest land" (96.67\%); "an outbreak of epidemics" (91.67\%) and "ill management practices" (75\%). Results are in agreement with the findings of Lidga et al. (2013), who reported that the major threats were depopulation of the areas and movement of livestock farming from the mountainous to plain zones, low productivity, low income and lack of professional organizations.

\section{Conclusions}

SWOT analysis is a systematic framework which helps to develop strategies by appraising the internal and external determinants of an enterprise. Internal environmental factors include risk taking abilities, human resource capabilities and financial strength. External factors include competition, government schemes, changing trends and social expectations. The SWOT analysis framework involves analyzing the strengths (S) and weakness (W) of the internal factors and the opportunities $(\mathrm{O})$ and threats $(\mathrm{T})$ of its external factors of performance. From the findings of study it can be concluded that the important strength of sheep and goat rearing was "traditional rearing practices of sheep and goat do not need high start up costs to establish a profitable business", whereas, "inaccessible paths to the sheep and goat rarer" was the major weakness. "Sheep and goat can be used as a tool to alleviate poverty while also ensuring food security" was considered as the main opportunity and major threat was "grazing areas are of difficult access to the shepherd". Based on SWOT analysis, strengths and opportunities should be exploited to optimize the productivity. The weaknesses and threats should be given utmost consideration and suitable strategies should be evolved to mitigate them.

\section{Conflict of Interest: Nil}

\section{References}

Anonymous (2010) Encyclopedia Britannica. Available on http://www.britannica.com access on $29^{\text {th }}$ August, 2018.
Arora CL, Garg RC (1998) Sheep production and Breeding. International Book distributing company, New Delhi.

Bosch RR, Diez-Unquera BD, Ruiz R, Villalba D, Molina E, Joy M, Olaizola A, Bernues A (2012) An integrated sustainability assessment of mediterranean sheep farms with different degrees of intensification. Agricultural Systems 105: 46-56.

Choudhary M (1999) The Gujjars over centuries In: Gujjars of Jammu and Kashmir. Himalayan research and cultural foundation, New Delhi, Pp: 84-91.

Gupta P, Gupta V, Ishar A, Vishal, Sharma V, Panotra N (2016) SWOT Analysis of Small Ruminants Rearing of Bakarwal Tribe in District Rajouri of Jammu and Kashmir. Journal of Animal Research 6: 1057-1060.

Kumara S, Reddy BS, Suresh SP (2017) Small Ruminant Production in Karnataka State of India- an Overview. European Journal of Zoological Research 5:28-35.

Legese G, Fadiga M (2014) Small ruminant value chain development in Ethiopia: Situation analysis and trends. ICARDA/ILRI Project Report. Nairobi, Kenya: International Center for Agricultural Research in the Dry Areas/ International Livestock Research Institute.

Ligda C, Sossidou E, Tzouramani I (2013) Domestic project: challenges and strategies for the sustainable development of the pastoral and rangeland sheep and goat production systems in Ipeiros (Epirus) region in Greece. Proceedings of the 10th international symposium on modern trends in livestock production held on October 2-4, 2013.

Rafaqi M (2014) A study of socioeconomic status among the Gujjar and Bakerwal tribal clans of J\&K. Asian Journal of Multidisciplinary Studies 2: 204-210. 